\title{
A controlled trial of a high fibre, low fat and low sodium diet for mild hypertension in Type 2 (non-insulin-dependent) diabetic patients
}

\author{
P. M. Dodson, P.J. Pacy, P. Bal, A.J. Kubicki, R. F. Fletcher and K. G. Taylor \\ Department of Diabetes and Endocrinology, Dudley Road Hospital, Birmingham, UK
}

Summary. Fifty hypertensive Type 2 (non-insulin-dependent) diabetic patients were allocated, in a controlled trial, to a treatment diet of high fibre, low fat and low sodium composition, or to a control diet by the hospital dietitian. After 3 months treatment, the modified diet-treated group showed a highly significant reduction in mean systolic $(180.5 \pm 19.0$ to $165.0 \pm 20.7 \mathrm{mmHg})$ and diastolic blood pressure $(96.6 \pm 9.3$ to $88.0 \pm 10.5 \mathrm{mmHg}$ ), accompanied by significant reductions in urinary sodium excretion (183.0 \pm 62.1 to $121.7 \pm$ $65.8 \mathrm{mmol} /$ day) glycosylated haemoglobin $(12.4 \pm 3.1$ to $10.5 \pm 2.9 \%$ ), weight $(74.6 \pm 13.5$ to $71.7 \pm 12.1 \mathrm{~kg}$ ) and serum triglyceride levels $(p<0.05)$. The mean values of diastolic pressure $(p<0.01)$, urinary sodium/potassium ratio $(p<$
$0.001)$, urinary potassium $(p<0.01)$ was significantly reduced at 3 months compared to control. No changes in serum HDLcholesterol levels were observed. The number of patients with normal blood pressure at 3 months was greater in the modified diet-treated group (ten versus five). Treatment of mild hypertension in diabetic subjects with this form of dietary regimen has a hypotensive response, with improvement in glycaemic control and no side effects. This modified diet may be an attractive alternative to anti-hypertensive drug therapy as a first line treatment.

Key words: Fibre, fat, sodium, hypertension, Type 2 diabetes.
Hypertension is common in diabetes $[1,3]$ but treatment may be far from satisfactory due to the adverse effects of anti-hypertensive drug therapy. In particular, thiazide and $\beta$-blocking drugs have been shown to produce deterioration in glycaemic control [4-6], an elevation of serum triglyceride levels and a reduction in high density lipoprotein cholesterol [7]. These effects may be of particular importance in the diabetic patient who is already at greater risk of premature atherosclerosis. An alternative to drug therapy in the treatment of hypertension would therefore be highly desirable.

Recent studies in non-diabetic hypertensive patients have suggested that dietary manipulations may reduce diastolic blood pressure; these include low sodium [8-10], low fat [11], high potassium [12] and high fibre intake $[13,14]$. The hypotensive effects of altering single dietary constituents is small, and therefore raises the possibility that a dietary regimen combining these alterations might have a more substantial effect. Indeed this has recently been reported in an uncontrolled [15] and in a community based study [16]. This form of dietary regimen has also been shown to produce improved glycaemic control with a reduction in cardiovascular risk factors in diabetic patients $[17,18]$. Excepting the low sodium and high potassium aspect, some of these di- etary changes are now recommended for diabetic patients by the British and American Diabetic Associations.

We have therefore assessed the effects of a dietary regimen consisting of high fibre, low fat und low sodium intake in three groups of diabetic hypertensive patients. An initial group of patients was studied as a pilot group and in view of the observed clinical benefit, a controlled study was then performed.

\section{Subjects and methods}

\section{Subjects}

Fifty Type 2 (non-insulin-dependent) diabetic hypertensive subjects attending Dudley Road Hospital were studied. The clinical characteristics of these patients were typical of Type 2 diabetes, although 11 were insulin-treated at the time of the study, owing to unsatisfactory diabetic control on oral hypoglycaemic agents. Twenty-five patients were allocated sequentially into control or modified diet treatment by the hospital dietitian (PB). Clinical details of these groups are shown in Table 1 and are comparable except for differences in initial mean systolic blood pressure, urinary sodium output and glycosylated haemoglobin $\left(\mathrm{HbA}_{1}\right)$ levels; these did not reach statistical significance. Informed consent was given by all the patients and the study was approved by the local Ethical Committee. 
Table 1. Clinical details of Type 2 diabetic hypertensive patients studied

\begin{tabular}{|c|c|c|c|c|c|c|c|c|}
\hline \multirow[t]{2}{*}{ Patient groups } & \multirow[t]{2}{*}{$\begin{array}{l}\text { Sex } \\
(M: F)\end{array}$} & \multirow[t]{2}{*}{$\begin{array}{l}\text { Age } \\
\text { (years) }\end{array}$} & \multirow{2}{*}{$\begin{array}{l}\text { Duration } \\
\text { of } \\
\text { diabetes } \\
\text { (years) }\end{array}$} & \multirow{2}{*}{$\begin{array}{l}\text { Body mass } \\
\text { index } \\
\left(\mathrm{kg} \div \mathrm{m}^{2}\right)\end{array}$} & \multicolumn{3}{|c|}{$\begin{array}{l}\text { Hypoglycaemic therapy } \\
\text { (no. of patients) }\end{array}$} & \multirow{2}{*}{$\begin{array}{l}\text { No. of } \\
\text { patients on } \\
\text { anti-hyper- } \\
\text { tensive } \\
\text { therapy }\end{array}$} \\
\hline & & & & & $\begin{array}{l}\text { Diet } \\
\text { alone }\end{array}$ & $\begin{array}{l}\text { Tablet } \\
\text { treated }\end{array}$ & $\begin{array}{l}\text { Insulin } \\
\text { treated }\end{array}$ & \\
\hline Control $(n=25)$ & $14: 11$ & $56.9 \pm 7.5$ & $6.4 \pm 6.3$ & $27.4 \pm 5.4$ & 13 & 6 & 6 & 7 \\
\hline Modified diet-treated $(n=25)$ & $11: 14$ & $56.6 \pm 7.2$ & $6.2 \pm 6.5$ & $28.1 \pm 4.9$ & 14 & 6 & 5 & 6 \\
\hline
\end{tabular}

Results expressed as mean $\pm \mathrm{SD}$

Table 2. Composition of the modified dietary regimen compared to a modern western diet

\begin{tabular}{|c|c|c|}
\hline & Trial $\operatorname{diet}^{\mathrm{b}}$ & $\begin{array}{l}\text { Modern } \\
\text { Western } \\
\text { Diet }^{\mathrm{a}} \text { (UK) }\end{array}$ \\
\hline Total energy (Kcal) & $\begin{array}{l}1600-2100 \\
(6.5-8.6 \mathrm{MJ})\end{array}$ & $\begin{array}{l}2,250 \\
(9.3 \mathrm{MJ})\end{array}$ \\
\hline Fat ( $\%$ total energy) & 25 & 40 \\
\hline Protein (\% total energy) & 22 & 13 \\
\hline $\begin{array}{l}\text { Unrefined carbohydrate } \\
\text { (\% total energy) }\end{array}$ & 50 & 26 \\
\hline $\begin{array}{l}\text { Refined carbohydrate } \\
\text { (\% total energy) }\end{array}$ & $\begin{array}{l}0-3 \\
\text { (includes } \\
\text { alcohol } \\
\text { intake) }\end{array}$ & 21 \\
\hline Dietary fibre (g/day) & $40-45$ & 20 \\
\hline Sodium (mmol/day) & $60-80$ & $\cong 180$ \\
\hline Potassium (mmol/day) & $80-90$ & $\cong 80$ \\
\hline Sodium/potassium ratio & $\cong 1.1$ & $2: 1$ \\
\hline
\end{tabular}

a Values for the modern diet of the United Kingdom are derived from the National Advisory Commission on Nutrition Education Report [23] and the Annual Report of the National Food Survey Committee [25].

b Values were calculated from four representative days on the intended diet by computerised food table analysis [26]

Criteria for entry to the study were three consecutive hypertensive readings (as defined by the World Health Organization: - systolic $>160 \mathrm{mmHg}$ or diastolic between 95 and $109 \mathrm{mmHg}$ ) in an established diabetic patient. Patients already receiving anti-hypertensive drug therapy were not excluded from the study, provided the above criteria for hypertension were met. Excluded were patients with evidence of diabetic or hypertensive nephropathy, cardiac failure or pregnancy.

\section{Methods}

All patients had previous hypertensive readings; the blood pressure was repeated after a 1 month run-in period and the mean of the two measurements determined. Blood pressure was recorded in the supine position after $5 \mathrm{~min}$ rest, with a random zero sphygmomanometer (Hawksley \& Sons, Lancing, Sussex, UK) by a separate 'blind' observer (MB) or by two of the authors (PP and PMD) taking diastolic blood pressure as the fifth Korotkoff phase. A standard width cuff $(14 \mathrm{~cm})$ was used if the mid-arm circumference was $<33 \mathrm{~cm}$, but if this was $>33 \mathrm{~cm}$, a large $(19 \mathrm{~cm})$ width cuff was used [19].

The diabetic hypertensive patients were all previously on low carbohydrate, high fat and low fibre diets (mean intake: $1650 \pm 400$ total calories) with $95 \%$ of patients adding salt to food at the table as well as in the cooking, on assessment by the hospital dietitian (PB).
Hypoglycaemic and anti-hypertensive medication remained the same for at least 1 month before and during the 3-month study period. At the end of the 1 month run-in period, patients were seen monthly for measurement of blood pressure, weight and 24-h-urinary sodium and potassium. Blood was taken before and after 3 months of the trial period for urea and electrolytes, liver function tests, glycosylated haemoglobin and fasting lipids.

$\mathrm{HbA}_{1}$ was measured by an affinity chromatography method using the Glyco-gel test kit (Pierce Chemicals, Rockford, Illinois, USA). Total serum cholesterol and triglyceride levels were measured by standard semi-automated methods (Baker Chemicals, Phillipsburg, New Jersey, USA). HDL cholesterol was measured by precipitating VLDL and LDL from $2 \mathrm{ml}$ of plasma with heparin $(750$ units in $100 \mu \mathrm{l})$ and $1 \mathrm{~mol} / 1 \mathrm{MnCl}_{2}(200 \mu \mathrm{l})$ as described previously [18]. No results were seen by the trial observers until the end of the study.

\section{Diet composition}

The composition of the intended modified diet given to 25 patients is shown in Table 2 . The regimen, made up from readily available foodstuffs, consisted of a high dietary fibre ( $40-45 \mathrm{~g} /$ day), high unrefined carbohydrate $(50 \%$ of total energy), low fat $(25 \%$ of total energy), low sodium $(60-80 \mathrm{mmol} / \mathrm{day})$, and normal potassium intake $(80-90 \mathrm{mmol} /$ day $)$. The daily calorie intake of $1600-2100 \mathrm{kcal}$ was standard for all patients given the modified diet and was comparable to the mean intake of patients before the trial. Patients were forbidden from adding salt at table or in cooking. In addition, a list of foods which had low fat and low salt content was given to the patients and they were instructed to eat whole food products; for example, wholemeal: bread, cereals, biscuits, pasta; brown rice and foods made with wholemeal flour. The increased fibre intake also incorporated durum hard wheat bran $(480 \mathrm{~g} / \mathrm{kg}$ dietary fibre, Pasta Foods, St. Albans, Herts, UK); patients were advised to incorporate this with the cereals taken at breakfast.

The hospital dietitian allocated patients to the modified dietary treatment or control group, dietary counselling was only performed on one occasion and equal time was given to both treatment groups.

The control group consisted of 25 patients who continued their former dietary regimen of low carbohydrate, low fibre and high fat content which was reinforced by the hospital dietitian. In particular, no advice concerning salt intake was given to this group of patients. However, they otherwise followed an identical trial protocol.

To assess palatability of this regimen, patients were given an anonymous questionnaire after 3 months of the modified diet treatment. Compliance to the dietary regimen was not individually assessed. However, a degree of compliance could be estimated to have occurred in the modified treatment group as a whole by the mean changes in the parameters measured, e.g. 24-h-urinary sodium output.

\section{Statistical analysis}

Analysis was by paired and unpaired Student's t-test. Statistical differences between the number of patients with normal blood pressure readings after 3 months were assessed by the $\chi^{2}$ test and correlations were made by the Pearson linear correlation coefficient. Multiple regression analysis was also performed on a SPSS Multics Computer System. 
Table 3. Summary of clinical changes observed after 3 months of the controlled trial

\begin{tabular}{cllll}
\hline & $\begin{array}{l}\text { Diet- } \\
\text { treated } \\
\text { group } \\
(n=25)\end{array}$ & $\begin{array}{l}\text { Signifi- } \\
\text { cance } \\
\text { between } \\
\text { groups }\end{array}$ & $\begin{array}{l}\text { Control } \\
\text { group } \\
(n=25)\end{array}$ \\
\hline Blood pressure (mmHg) & & & \\
Systolic: & Start & $180.5 \pm 19.0$ & NS & $170.0 \pm 20.0$ \\
& Finish & $165.0 \pm 20.7$ & NS & $164.2 \pm 17.8$ \\
& & $p<0.001$ & & NS \\
Diastolic: & Start & $96.6 \pm 9.3$ & NS & $97.0 \pm 7.1$ \\
& Finish & $88.0 \pm 10.5$ & $p<0.01$ & $95.4 \pm 8.7$ \\
& & $p<0.001$ & & NS
\end{tabular}

Body weight $(\mathrm{kg})$

$\begin{array}{lccc}\text { Start } & 74.6 \pm 13.5 & \text { NS } & 74.2 \pm 16.7 \\ \text { Finish } & 71.7 \pm 12.1 & \text { NS } & 73.7 \pm 15.9 \\ & p<0.01 & & \text { NS }\end{array}$

Normal blood pressure

achieved (no. of patients)

$$
\text { At } 3 \text { months } \quad 10(40 \%) \quad \text { NS } \quad 5(20 \%)
$$

Results expressed as mean \pm SD. Statistical significance of a difference between groups is shown between colums (unpaired t-test) and significance of a change within a group is shown below the finishing figure (paired t-test)

\section{Results}

The changes in systolic and diastolic blood pressure and weight in the 25 patients treated with the modified diet are shown in Table 3.

Highly significant mean changes were observed in the controlled trial during and at 3 months. In particular, a significant reduction of mean systolic blood pressure was observed at $1(p<0.05)$ and 3 months $(p<$ 0.001 ), but the values were not significantly different from control. However, mean diastolic blood pressure fell significantly in both modified diet treated $(p<$ $0.001)$ and control group $(p<0.02)$ at 1 month, but mean values of the control subsequently returned to near to the initial reading at 3 months. In contrast, the modified diet treated group had a further significant fall in diastolic blood pressure at 3 months, which was also significantly different from the 3 month control value $(p<$ 0.02 ). The number of patients with normal blood pressure at 3 months was also greater in the modified diettreated group compared with control. These blood pressure changes were also accompanied by significant weight loss $(p<0.001)$, significant reductions in the urinary sodium output $(p<0.001)$ and urinary sodium/potassium ratio $(p<0.001)$ and the 3 month mean values of both these parameters were also significantly lower compared with control levels $(p<0.05$ and $p<0.001$ respectively). However no change was observed in mean urinary potassium excretion in either groups, although the 3 month value in the diet-treated group was significantly higher than that of control $(p<0.01)$. A significant improvement in glycaemic control as measured by
Table 4. Summary of biochemical changes observed after 3 months of the controlled trial

\begin{tabular}{|c|c|c|c|c|}
\hline & & $\begin{array}{l}\text { Diet } \\
\text { treated } \\
\text { group } \\
(n=25)\end{array}$ & $\begin{array}{l}\text { Signifi- } \\
\text { cance } \\
\text { between } \\
\text { groups }\end{array}$ & $\begin{array}{l}\text { Control } \\
\text { group } \\
(n=25)\end{array}$ \\
\hline \multicolumn{5}{|c|}{ Urinary electrolyte excretion ( $\mathrm{mmol} / 24 \mathrm{~h})$} \\
\hline Sodium: & $\begin{array}{l}\text { Start } \\
\text { Finish }\end{array}$ & $\begin{array}{l}183.0 \pm 62.1 \\
121.7 \pm 65.8 \\
p<0.001\end{array}$ & $\begin{array}{l}\text { NS } \\
p<0.05\end{array}$ & $\begin{array}{l}156.8 \pm 62.5 \\
164.8 \pm 59.5 \\
\text { NS }\end{array}$ \\
\hline Potassium: & $\begin{array}{l}\text { Start } \\
\text { Finish }\end{array}$ & $\begin{array}{l}66.9 \pm 21.4 \\
71.7 \pm 26.9 \\
\text { NS }\end{array}$ & $\begin{array}{l}\text { NS } \\
p<0.01\end{array}$ & $\begin{array}{l}61.7 \pm 20.8 \\
51.7 \pm 19.6 \\
\mathrm{NS}\end{array}$ \\
\hline $\begin{array}{l}\mathrm{Na} / \mathrm{K} \\
\text { molar ratio: }\end{array}$ & $\begin{array}{l}\text { Start } \\
\text { Finish }\end{array}$ & $\begin{array}{r}2.92 \pm 1.12 \\
1.78 \pm 0.73 \\
p<0.001\end{array}$ & $\begin{array}{l}\text { NS } \\
p<0.001\end{array}$ & $\begin{aligned} 2.65 \pm 0.88 \\
3.44 \pm 1.30 \\
\text { NS }\end{aligned}$ \\
\hline Glycosylated ha & $\begin{array}{l}\text { moglobir } \\
\text { Start } \\
\text { Finish }\end{array}$ & $\begin{array}{l}12.4 \pm 3.1 \\
10.5 \pm 2.9 \\
p<0.001\end{array}$ & $\begin{array}{l}\text { NS } \\
\text { NS }\end{array}$ & $\begin{array}{l}10.7 \pm 3.3 \\
10.6 \pm 2.9 \\
\mathrm{NS}\end{array}$ \\
\hline $\begin{array}{c}\text { Fasting serum li } \\
\text { Cholesterol: }\end{array}$ & $\begin{array}{l}\text { ids (mmo } \\
\text { Start } \\
\text { Finish }\end{array}$ & $\begin{array}{l}\text { (l) } \\
5.6 \pm 1.5 \\
5.5 \pm 1.2 \\
\mathrm{NS}\end{array}$ & $\begin{array}{l}\text { NS } \\
\text { NS }\end{array}$ & $\begin{array}{l}6.1 \pm 1.9 \\
6.2 \pm 2.9 \\
\mathrm{NS}\end{array}$ \\
\hline Triglyceride: & $\begin{array}{l}\text { Start } \\
\text { Finish }\end{array}$ & $\begin{array}{l}1.8 \pm 0.9 \\
1.5 \pm 0.8 \\
p<0.05\end{array}$ & $\begin{array}{l}\text { NS } \\
\text { NS }\end{array}$ & $\begin{array}{l}1.8 \pm 1.4 \\
2.2 \pm 2.9 \\
\mathrm{NS}\end{array}$ \\
\hline $\begin{array}{l}\text { HDL- } \\
\text { cholesterol: }\end{array}$ & $\begin{array}{l}\text { Start } \\
\text { Finish }\end{array}$ & $\begin{array}{r}1.3 \pm 0.5 \\
1.3 \pm 0.3 \\
\text { NS }\end{array}$ & $\begin{array}{l}\text { NS } \\
\text { NS }\end{array}$ & $\begin{array}{l}1.6 \pm 0.5 \\
1.4 \pm 0.3 \\
\mathrm{NS}\end{array}$ \\
\hline
\end{tabular}

Results expressed as mean \pm SD. Statistical differences recorded as stated in Table 3

$\mathrm{HbA}_{1}(p<0.001)$, with a significant reduction in serum triglyceride levels $(p<0.01)$, was also observed but there were no significant alterations in HDL cholesterol levels. No significant differences were observed between female and male patients when analysed separately. Analysis of the questionnaire $(n=49)$ revealed that 33 of the diet-treated patients $(68 \%)$ were prepared to stay on this dietary regimen for life, 39 expressed feeling in better health $(80 \%)$, and only three $(6 \%)$ claimed that the dietary regimen was impossible to adhere to.

To elucidate which of the clinical and biochemical changes might be contributing to a reduction in blood pressure, Pearson linear correlations were performed in the control group and in all patients treated with the modified dietary regimen, which also included a group of 25 Type 2 diabetic hypertensive patients treated prior to the controlled trial as a pilot group (Table 4). Positive significant correlations $(n=75)$ were shown between reduction in urinary sodium/potassium ratio and urinary sodium output, with both systolic $(r=+0.387, p<0.001$ and $r=+0.221, p<0.03$, respectively) and diastolic blood pressure $(r=+0.370, p<0.001$ and $r=+0.266$, $p<0.01$, respectively). Multiple regression confirmed that the reduction in urinary sodium/potassium ratio was the most important factor related to both systolic 
and diastolic blood pressure reduction ( $p<0.0006$ and $p<0.001$, respectively). No significant correlations were found between changes in diastolic blood pressure and weight or $\mathrm{HbA}_{1}$. However, although no significant correlations were found between changes in systolic blood pressure and $\mathrm{HbA}_{1}$, a significant correlation was noted with weight loss $(r=+0.312, p<0.01)$. No significant association was demonstrated between either change in serum cholesterol or triglyceride levels with changes in systolic or diastolic blood pressure.

Evidence that weight loss per se was not the main factor in the diastolic hypotensive response was shown in six patients whose weight remained constant on the modified dietary regimen $(64.8 \pm 3.9$ versus $64.7 \pm$ $3.9 \mathrm{~kg}$ ) as significant falls were observed of diastolic blood pressure $(93.3 \pm 2.3$ to $82.7 \pm 3.1 \mathrm{mmHg}: p<$ $0.001)$, urinary sodium $(220.8 \pm 24.6$ to $139.3 \pm$ $20 \mathrm{mmol} / 24 \mathrm{~h}, p<0.01)$ and $\mathrm{HbA}_{1} 9.9 \pm 0.4$ to $8.1 \pm$ $0.8 \%, p<0.05$ ). A positive association was noted between reduction in $\mathrm{HbA}_{1}$ and serum triglyceride levels $(r=+0.484, p<0.001)$ but no association was shown between weight loss and reduction in $\mathrm{HbA}_{1}$ or urinary sodium output.

\section{Discussion}

The important finding of this study is a significant fall in both diastolic and systolic blood pressures on a modified dietary regimen. This was also accompanied by improvement in glycaemic control, reduction in serum triglyceride levels with no alteration in HDL-cholesterol levels, weight loss and feeling of well-being. This is in contrast to the effects of common anti-hypertensive drug therapy which may be associated with worsening of glycaemic control, and an increase of serum triglyceride with a reduction in HDL-cholesterol levels, and multiple side effects [4-7]. Furthermore, a greater number of patients had normal blood pressure at the end of the 3-month trial period, therefore reducing the number of patients who would have otherwise received antihypertensive drug therapy.

These findings are also in agreement with similar uncontrolled and controlled studies for non-diabetic essential hypertensive patients $[15,16]$. In particular, Beard et al. reported a reduction in anti-hypertensive drug therapy on a similar regimen [16].

Consideration of the analysis of these data with regard to allocation of patients and 'blind' conditions is important. The method of allocation used in this trial, sequential by the hospital dietitian, may account for the differences in the initial mean systolic blood pressures, urinary sodium output and $\mathrm{HbA}_{1}$ level. Although the blood pressure observers were initially 'blind' as to the patient's trial group, it became clear later in the trial which group the patient belonged to, usually by the questions and other comments made by the patient, so the trial was not truly "blind". However, the use of the random zero sphygmomanometer should have overcome observer bias in blood pressure measurement. Furthermore, all patients, including the control groups, followed exactly the same trial protocol.

The exact mechanism of the hypotensive effect of this dietary regimen is not clear. There was a significant weight loss on the modified diet which might be one important factor, as it has an independent effect on blood pressure when sodium intake is held constant [20]. Weight loss does not appear to be a major factor in this trial in view of the lack of a statistical association between weight change and fall in diastolic blood pressure, and the highly significant diastolic hypotensive response noted in those patients whose weight remained constant during the trial period. The mean weight loss of the modified diet-treated group may represent water loss due to the lower sodium intake, although no statistical association between these factors was shown. However, it is clear from other studies that some of the hypotensive effect must be attributed to the reduction in sodium output [8-10]; this is suggested by the positive statistical association of this and both systolic and diastolic blood pressure reduction in our study. However, other factors may be important and include the high fibre and low fat aspect of the diet [13,14], although no association was observed between changes in either serum cholesterol or triglyceride levels and blood pressure.

The improvement in glycaemic control is most likely to be due to the high fibre and unrefined carbohydrate aspect of the diet as these dietary alterations have been well documented to produce improved diabetic control [17]. This change is also the most likely explanation for the reduction in serum triglyceride levels in view of the positive statistical association of these two factors observed in this study. Weight loss, however, must also be considered in this context but we could show no association between this and reduction in $\mathrm{HbA}_{1}$.

The degree of compliance with the modified dietary regimen was not assessed in individual patients. However it is clear that a considerable degree of compliance must have occurred in the modified diet-treated group because of the mean reductions of weight, $\mathrm{HbA}_{1}$, serum triglyceride levels and urinary sodium output, none of which was observed in the control group. It must, however, be noted that the mean reduction of urinary sodium excretion was approximately half of what would have been predicted from the analysis of the intended dietary regimen, suggesting compliance was not complete in reduction of sodium intake.

The purpose of the present trial was to ascertain the effect of a high fibre, low fat and low sodium regimen on blood pressure and glycaemic control. A clear hypotensive response has been shown with improved diabetic control which is in contrast to the effects of anti-hypertensive drug therapy. Of particular concern with regard to possible harmful effects of drug therapy, is the report by the Multiple Risk Factor Intervention Trial 
study of a greater number of deaths from coronary heart disease in hypertensive patients with ECG abnormalities who received aggressive anti-hypertensive treatment compared with those who did not [21]. The Australian therapeutic trial has also cast concern about drug treatment of mild hypertension [22].

Long-term compliance and palatability of this form of dietary regimen is a crucial question and at present is unknown. One recent report of 19 non-diabetic hypertensive patients treated with this diet has shown that the reduction in anti-hypertensive medication and cardiovascular risk was similar at 3 months and after 4 years of follow-up [23]. We propose therefore to extend the present study to include at least a 1-year follow-up period. It is also of interest that a similar number of patients $(68 \%)$ in our study compared to that of Beard et al. $(67 \%)[16]$ found the dietary regimen palatable and that it was a viable diet in the long-term.

The results of this study suggest that this form of dietary regimen should be considered as a first line treatment in the mildly hypertensive diabetic patient and may be an attractive alternative to drug therapy.

Acknowledgements. P.J.Pacy is a Wellcome Research Fellow. We are grateful to: Miss L. Walker, Mrs. S. Bradbury and Miss R. Hallworth for assistance with dietary counselling, Mrs. B.Singh for secretarial assistance, Mrs. M. Beevers and Miss A. Franklin for assistance with the SPSS Multics Computer System and Pasta Foods (St. Albans, Herts, UK) for supplying the durum hard wheat bran.

\section{References}

1. Christlieb AR, Warran JH, Krolewski AS, Busick EJ, Ganda OM, Asmal AC, Soeldner JS, Bradley RF (1981) Hypertension: the major risk factor in juvenile onset insulin dependent diabetics. Diabetes 30 (Suppl 2): 90-96

2. Barrett-Connor E, Criqui MH, Klauber MR, Holdbrook M (1981) Diabetes and hypertension in a community of older adults. Am J Epidemiol 113: 276-284

3. Pacy PJ, Dodson PM, Beevers M, Fletcher RF, Taylor KG (1983) The ethnic prevalence of hypertension in a diabetic clinic. Postgrad Med J 59: 56-59

4. Murphy MB, Lewis PJ, Kohner E, Schumer B, Dollery CT (1982) Glucose intolerance in hypertensive patients treated with diuretics; a fourteen year follow-up. Lancet 2: 1293-1295

5. Waal-Manning HJ (1976) Metabolic effects of beta-adrenoreceptor blockers. Drugs 11 (Suppl 1): 121-126

6. Gundersen T, Kjekshus J (1983) Timolol treatment after myocardial infarction in diabetic patients. Diabetes Care 6:285-290

7. Dodson PM (1982) Lipids and antihypertensive therapy. Br J Clin Pract Suppl 20: 17-20

8. MacGregor GA, Markandu ND, Best FE, Elder DM, Cam DM, Sagnella GA, Squires M (1982) Double blind randomised crossover trial of moderate sodium restriction. Lancet 1: 351-354
9. Parijs J, Joossens JV, Van der Linden L, Verstreken G, Amery A (1973) Moderate sodium restriction and diuretics in the treatment of hypertension. Am Heart J $85: 22-34$

10. Morgan T, Gillies A, Morgan G, Adam W, Wilson M, Carney S (1978) Hypertension treated by salt restriction. Lancet 1: 227-230

11. Puska P, Iancono J, Nissinen A, Korhonen $H$, Vartiainen E, Pietinen P, Dougherty R, Leino V, Mutanen M, Moisio S, Huttunen J (1983) Controlled randomised trial of the effect of dietary fat on blood pressure. Lancet 1: 1-5

12. MacGregor GA, Smith SJ, Markandu ND, Banks RA, Sagnella GA (1982) Moderate potassium supplementation in essential hypertension. Lancet 2: $567-570$

13. Rouse IL, Beilin LJ, Armstrong BK, Vandongen R (1983) Blood pressure-lowering effect of a vegetarian diet: controlled trial in normotensive subjects. Lancet 1: 5-9

14. Wright A, Burstyn PG, Gibney MJ (1979) Dietary fibre and blood pressure. Br Med J 2: 1541-1543

15. Dodson PM, Humphreys DM (1981) Hypertension and angina. In: Trowell HC, Burkitt DP (eds) Western diseases: their emergence and prevention. Edward Arnold, London, pp 411-420

16. Beard TC, Cooke HM, Gray WR, Barge R (1982) Randomised controlled trial of a no-added-sodium diet for mild hypertension. Lancet 2: 455-458

17. Simpson RW, Mann JI, Eaton J, Carter RD, Hockaday TDR (1979) High-carbohydrate diets and insulin-dependent diabetics. Br Med J 2: 523-525

18. Dodson PM, Stocks J, Holdsworth G, Galton DJ (1981) Highfibre and low-fat diets in diabetes mellitus. Br J Nutr 46: 289-294

19. Maxwell MH, Waks AV, Schroth PC, Karam M, Dornfield LP (1982) Error in blood pressure measurement due to incorrect cuff size in obese patients. Lancet 2: 33-35

20. Reisin E, Abel R, Modam M, Silverberg DS, Eliahou HE, Modan B (1978) Effect of weight loss without salt restriction on reduction of blood pressure in overweight hypertensive patients. N Engl J Med 289: 1-6

21. Multiple Risk Factor Intervention Trial (1982) JAMA 248: 1465-1477

22. The Australian Therapeutic Trial in Mild Hypertension (1980) Lancet 1: 1261-1267

23. Pacy P, Dodson PM (1984) Hypertension and wellbeing. Br Med J 288: 327 (Letter)

24. National Advisory Committee on Nutrition Education (1983) Proposals for nutritional guidelines for health education in Britain. Lancet 2: 719-721, 782-785, 835-837, 902-905

25. Ministry of Agriculture, Fisheries and Food (1979) Household food consumption and expenditure. Her Majestry's Stationary Office, London, $\mathrm{p} 111$

26. Paul AA, Southgate DAT (1978) In: McCance and Widdowson's, The composition of foods, 4th edn. Her Majesty's Stationary Office, London

Received: 22 December 1983

and in final form: 8 August 1984

Dr. P. M. Dodson

Clinical Investigation Unit

Dudley Road Hospital

Birmingham B18 7QH

West Midlands

UK 